University of South Carolina

Scholar Commons

5-1-1997

\title{
Intraspecific and Diffuse Competition: The Response of Nassella pulchra in a California Grassland
}

Andrew R. Dyer

University of South Carolina, Aiken, AndyD@usca.edu

Kevin J. Rice

University of California, Davis

Follow this and additional works at: https://scholarcommons.sc.edu/aiken_biology_geology_facpub

Part of the Biology Commons, Botany Commons, and the Weed Science Commons

\section{Publication Info}

Published in Ecological Applications, Volume 7, Issue 2, 1997, pages 484-492.

(C) 1997 by the Ecological Society of America.

Dyer, A., \& Rice, K. (1997). Intraspecific and Diffuse Competition: The Response of Nassella Pulchra in a California Grassland. Ecological Applications, 7(2), 484-492. https://doi.org/ 10.1890/1051-0761 inclusion in Faculty Publications by an authorized administrator of Scholar Commons. For more information, please contact digres@mailbox.sc.edu. 


\title{
INTRASPECIFIC AND DIFFUSE COMPETITION: THE RESPONSE OF NASSELLA PULCHRA IN A CALIFORNIA GRASSLAND
}

\author{
A. R. DYeR ${ }^{1,3}$ AND K. J. RICE ${ }^{1,2}$ \\ ${ }^{1}$ Department of Agronomy and Range Science, University of California, Davis, California 95616 USA \\ ${ }^{2}$ Center for Population Biology, University of California, Davis, California 95616 USA
}

\begin{abstract}
In inland California grasslands, the high densities of alien annual species have altered the growing environment for native perennial grasses. Using variable-density plots, we measured the influence of intraspecific competition (conspecifics only) and diffuse competition (mixed-composition neighborhoods that include conspecifics) on growth and survival of Nassella pulchra, purple needlegrass. We assessed the effects of intraspecific and diffuse competition in weeded plots and unweeded plots, respectively, across a density gradient of $N$. pulchra plants (16-356 plants $\left./ \mathrm{m}^{2}\right)$. We used summer fire and spring sheep grazing to reduce diffuse competition in unweeded plots. The potential effect of rooting volume on competitive interactions was explored by establishing plots on two sites of different soil depth. Diffuse competition had an overriding influence on $N$. pulchra growth in all treatments. Intraspecific competitive effects were apparent only in the absence of diffuse competition. The effects of grazing and soil depth on growth were only short-lived interactions with the burning treatment. Burning was a longer-lived interaction, but only in weeded plots. Plant mortality was significantly increased by diffuse competition. Overall, $N$. pulchra survival was greatest in weeded plots, in grazed plots, and in deeper soil plots. The growth of $N$. pulchra individuals was negatively affected by alien annual species in all treatment combinations. Our data indicate that recruitment of $N$. pulchra within inland California grasslands is reduced by the adverse environment created by high densities of alien annual species. Successful attempts to increase populations of N. pulchra through management of the grassland community must involve significant modification of the biotic environment.
\end{abstract}

Key words: California annual grassland; competitive suppression; diffuse competition; grassland restoration; interspecific competition; intraspecific competition; Nassella pulchra; perennial bunchgrass; purple needlegrass.

\section{INTRODUCTION}

Although originally dominated by perennial grasses (Clements 1934, Burcham 1957, Heady 1988), the Central Valley and foothill grasslands have been converted over the past two centuries to a predominantly annual system (Burcham 1957, Mack 1989) with native perennial grasses generally displaced from the valley floor (Huenneke 1989). The conversion process was coincident at different times with several landscapelevel influences, including intensive grazing by livestock, suppression of wildfire, prolonged periods of below average precipitation, and invasion by alien species (Burcham 1957, Bartolome and Gemmill 1981, Mack 1989). These influences on the grasslands occurred throughout California and, with the exception of heavy grazing and outright agricultural conversion, generally involved little physical disturbance.

Most presettlement grasslands were probably dominated by bunchgrasses with Nassella pulchra (Hitchc.)

Manuscript received 22 November 1995; revised 2 May 1996; second revision 29 May 1996; accepted 4 July 1996.

${ }^{3}$ Present address: Mitrani Center, Jacob Blaustein Institute for Desert Ecology, Ben Gurion University, Midreshet BenGurion, 84990 Israel.
Barkworth the most widespread and abundant (Clements 1934, Burcham 1957, Heady 1988). Today, however, alien species in grassland habitats occur in such high densities that they now define the system (e.g., the "California annual system") (Talbot et al. 1949, McNaughton 1968, Heady 1988). These species are primarily native to Europe and preadapted to the mediterranean-type climate of the California grasslands (Jackson 1985). Consequently, the environment of contemporary grasslands is now potentially very different from that in which native species evolved (Evans and Young 1972).

After the first significant precipitation in fall, thousands of nonnative annuals per square meter germinate and emerge (Major and Pyott 1966). As a consequence, intraspecific competition among native plants may be weak because the neighborhood of a Nassella seedling may be composed of hundreds of individuals of many species (Bartolome 1979). An estimate of the presettlement density of mature N. pulchra based on soil opal phytolith data was 4.2 plants/ $\mathrm{m}^{2}$ (Bartolome et al. 1986); other studies of $N$. pulchra have reported a range of 1-7 mature plants $/ \mathrm{m}^{2}$ (White 1967, Bartolome and Gemmill 1981, Heady et al. 
1992). The competition provided by several large bunchgrasses compared to that of hundreds of annual grasses is unknown. As a result of the changes in composition of inland California grasslands, theoretical models such as those using nearest neighbor distances may not appropriately characterize the competitive environment (Berendse 1983).

We hypothesize that the high densities of nonnative annual species, especially grasses, have fundamentally altered the environment experienced by $N$. pulchra seedlings. Whereas intraspecific interactions may have had a significant influence on $N$. pulchra before the introduction of alien annuals, "diffuse competition" (sensu MacArthur 1972:45, Wilson and Keddy 1986, Goldberg 1987) from these alien annuals has now become more important. In this paper, the phrase "diffuse competition" will be used to signify a competitive neighborhood composed of high densities of many species, including conspecifics of the target plants. In such a neighborhood, the addition or removal of a single neighbor has an insignificant effect on the competition experienced by a target plant.

The decline of perennial grasses in inland grasslands has been attributed to intense grazing coincident with periods of below average precipitation (Burcham 1957, Heady et al. 1992) and the invasion of many alien annual species. However, with average precipitation and reduced grazing, the return to dominance of perennial grasses has not occurred (White 1967, Bartolome and Gemmill 1981). In addition, attempts to restore perennial grass populations via seeding techniques achieve little success unless populations of alien species are reduced or eliminated (Evans and Young 1972, Dyer et al. 1996, Stromberg and Griffin 1996). These observations suggest a strong interaction between alien species and native perennial species during the early stages of establishment and growth.

Prescribed fire and grazing by livestock have been recommended as tools to reduce the suppression of native vegetation by annual grass biomass (Menke 1992). We attempted to manipulate the intensity of diffuse competition with seasonal sheep grazing and prescribed burning, in combination with differences in soil depth. We measured the relative effects of intraspecific and diffuse competition on the survival and growth of $N$. pulchra across a range of planting densities. Differences in the growth response of $N$. pulchra between the two competition environments provided a measure of the impact of alien species. Our objective was to assess the general effectiveness of burning and grazing as grassland management strategies for increasing $N$. pulchra abundance and reducing competition from annual species.

\section{Methods}

This study was conducted at the Jepson Prairie Reserve in Solano County, California. The area is characterized by a "Mima" mound topography (Holland and Jain 1988), and is underlain by an impervious clay layer at a depth of $\approx 20 \mathrm{~cm}$ in intermound areas, and $\approx 65 \mathrm{~cm}$ under mounds. The underlying clay creates a perched water table during winter and spring that results in a seasonally wet "vernal pool" environment in the lowest intermound areas. The soil at the Reserve is classified as San Ysidro sandy loam (fine, montmorillonitic, thermic, Typic Palexeralfs).

Spatial distribution of $N$. pulchra within the vernal pool habitat at Jepson Prairie reflects the topography of the site. Typically, mature N. pulchra plants occur in higher numbers on mounds; fewer occur in the intermound areas, and virtually none in the vernal pools. Changes in floristic composition and edaphic conditions occur along a topographic gradient from mounds to intermounds to vernal pools. Along the gradient, vegetative cover (point frame method) ranges from $100 \%$ on mounds to $<30 \%$ in vernal pools. The percentage of native species ranges from zero on mounds to $>70 \%$ in vernal pools; and the percentage of alien annual species ranges from $100 \%$ on mounds to $<7 \%$ in vernal pools. The intermound areas are generally intermediate for these characteristics (Holland and Jain 1988).

Eighteen experimental areas $(20 \times 20 \mathrm{~m})$ (Fig. 1b) were established in 1988, with six treatment combinations of two levels of prescribed burning and three levels of grazing by sheep, in a full-factorial, randomized complete block design with three replications (2 $\times 3 \times 3=18$ ) (Fig. 1c). The grazing treatment was applied annually in April (spring) or in August (summer); prescribed burns took place on 1 September 1988 and on 13 September 1991. Ungrazed and unburned controls were included in the design.

N. pulchra seed was collected in 1988 from 18 large individuals from each of the 18 experimental areas. The bulked seed was planted in trays filled with potting soil in November 1990 and germinated in a glasshouse. Seedlings were transferred to $4 \mathrm{~cm}$ diameter $\times 14 \mathrm{~cm}$ long plastic tubes when 2-3 wk old, grown in the glasshouse under ambient light for $6 \mathrm{wk}$, then cold hardened outside the glasshouse until planted.

Individual Nassella plants were planted into 24, variable density, "fan" plots (Antonovics and Fowler 1985) from 17 February-7 March 1991 in both mound and intermound locations in the unburned experimental areas that were spring grazed or ungrazed. The fanstyle plots allowed several planting densities to be analyzed within a single plot (Fig. 1a). Each plot was composed of 12 rows, with six individuals per row within a total area of about $0.75 \mathrm{~m}^{2}$. The spacing in Row 3 was $4 \mathrm{~cm}$ between plants. The distance to plants in the next row was $5 \mathrm{~cm}$ (an increase of $25 \%$ ), and spacing between plants within that row was also $5 \mathrm{~cm}$. Distances between succeeding rows and between individuals within rows were increased by $25 \%$, so that the distance between plants within Row 12 was $29 \mathrm{~cm}$. 

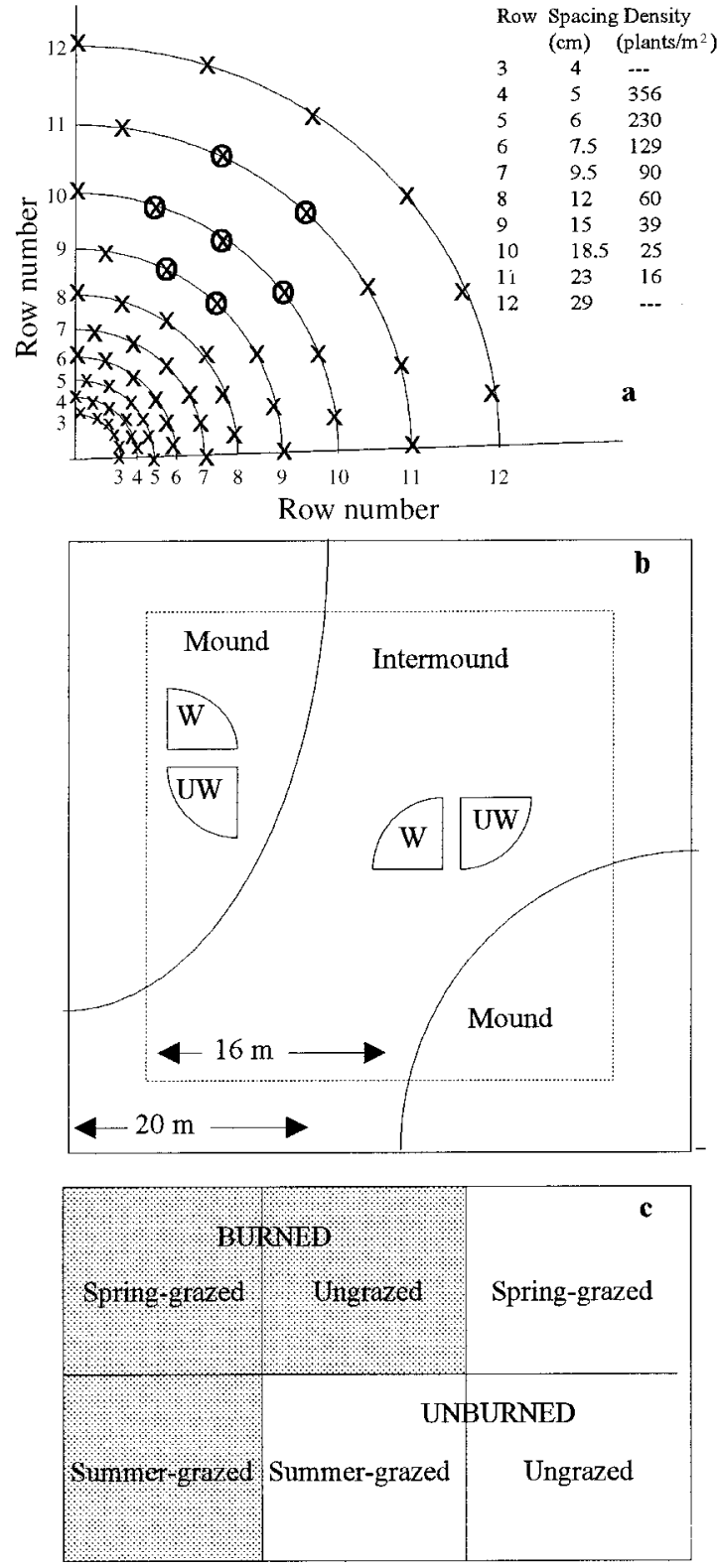

FIG. 1. Experimental design showing plots, experimental areas, and replicated blocks. (a) Fan plot with eight rows bounded by two buffer rows (Rows 3 and 12) with four target plants per row and two buffer plants (first and last in the row). Plants shown with circles indicate the hexagonal arrangement within the plot. Spacing is in $\mathrm{cm}$; density is in plants $/ \mathrm{m}^{2}$. (b) Experimental area showing weeded and unweeded plot pairs on two locations of different soil depth (mound and intermound). The outer $2 \mathrm{~m}$ of each experimental area was considered a buffer zone. (c) Replicated unit showing six experimental areas in a full factorial of burning and grazing treatment combinations. No fan plots were planted in summergrazed areas.

Every target plant was surrounded by six neighbors in a hexagonal pattern.

To assess the effect of fire on plant growth, a second set of 24 plots was planted from 23 February-17 March
1992 in spring grazed and ungrazed experimental areas that had been burned the previous fall. Seeds from the same bulk collection were planted directly into plastic tubes, then grown and planted in the same manner as described for the first set of plots. No plots were planted in summer grazed areas.

Pairs of plots were planted in both mound and intermound areas within each experimental area. Within each mound and each intermound, the two plots were placed side by side (Fig. 1b). One was cleared of all living vegetation except the target plants, the other was left unweeded. Removal of vegetation from weeded plots occurred annually in early March with subsequent weeding to remove late-germinating plants. Plots were dropped from the study when overall mortality exceeded $30 \%$, or when mortality of target plants severely compromised the density treatment.

We allowed the plots to establish during the first growing season; we did not take growth measurements until the end of the second growing season. We assessed growth in target plants by measuring changes in basal diameter, because increase in basal diameter in $N$. pulchra was highly correlated with above ground biomass $(r=0.92$; A. R. Dyer, unpublished data). Basal diameter was measured in millimeters using digital calipers in early July of each year. Perpendicular measurements of the long and short axes were taken on plants that were not circular in shape. The values were used to approximate the area of an ellipse using the formula

$$
\text { Area } \cong\left(r_{1}-2 r_{\mathrm{s}}\right) r_{\mathrm{s}}+\pi r_{\mathrm{s}}^{2}
$$

where $r_{1}$ is the length of the long axis and $r_{\mathrm{s}}$ is the length of the short axis. The diameter of a circle was calculated with the area value thus generated using the formula

$$
\text { Diameter }=2(\text { Area } / \pi)^{1 / 2}
$$

and that value was substituted for the original measurements and used in further analysis. All plants were measured in both unburned plots and burned plots after the second and third growing seasons, and in the unburned plots after the fourth season. Censuses were conducted in March and July of each year.

Analysis was performed on data from Rows 4-11 only (5-23 cm spacing), because the highest density Rows 1 and 2 experienced high mortality in the first year (see Discussion). Rows 3 and 12 were considered buffer rows, as were the first and last plants in each row. As a result, a total of 32 plants were used for analysis of each plot ( $n=$ four plants per density per plot).

The effect of treatments on plant basal diameter $(\mathrm{mm})$ and mortality (arcsine-square root of percent annual loss) were analyzed using the SAS General Linear Model (Littell et al. 1991) with burning and grazing as main effects, soil depth (about $65 \mathrm{~cm}$ on mounds and $20 \mathrm{~cm}$ on intermounds) as a subplot treatment, and 
TABle 1. Analysis of the increase in basal diameter $(\mathrm{mm})$ of Nassella pulchra at Jepson Prairie, California, in response to burning and grazing treatment combinations, soil depth, and planting density. Planting density was used as a covariate in the analysis. No analysis of a grazing effect was possible in the third and fourth years. There was no replication in the fourth year; the data were analyzed as a complete randomized design.

\begin{tabular}{|c|c|c|c|c|c|c|c|c|c|}
\hline \multirow[b]{2}{*}{ Treatment } & \multicolumn{3}{|c|}{ Second year } & \multicolumn{3}{|c|}{ Third year } & \multicolumn{3}{|c|}{ Fourth year } \\
\hline & df & MS & $F$ & df & MS & $F$ & $\mathrm{df}$ & MS & $F$ \\
\hline \multicolumn{10}{|l|}{ Weeded plots only } \\
\hline Burn and grazing $\times$ soil depth & 3 & 55.40 & $4.85 * *$ & 1 & 0.52 & 0.01 & & & \\
\hline Planting density & 1 & 1248.51 & $109.41 * * *$ & 1 & 1702.55 & $45.12 * * *$ & & & \\
\hline Burn and grazing $\times$ density & 3 & 48.50 & $4.25 * *$ & 1 & 50.71 & 1.34 & & & \\
\hline Error & 108 & 11.41 & & 53 & 37.73 & & & & \\
\hline Total & 130 & & & 64 & & & & & \\
\hline \multicolumn{10}{|l|}{ Burned plots only } \\
\hline Weeded & 1 & 1822.72 & $169.13 * * *$ & 1 & 967.88 & $30.58 * * *$ & & & \\
\hline Soil depth $\times$ weeded & 1 & 63.72 & $5.91 *$ & 1 & 33.37 & 1.05 & & & \\
\hline Planting density & 1 & 724.26 & $67.21 * * *$ & 1 & 431.25 & $13.63 * * *$ & & & \\
\hline Weeded $\times$ density & 1 & 357.33 & $33.16 * * *$ & 1 & 167.96 & $5.31 *$ & & & \\
\hline Error & 104 & 10.78 & & 56 & 31.65 & & & & \\
\hline Total & 121 & & & 65 & & & & & \\
\hline \multicolumn{10}{|l|}{ Unburned plots only } \\
\hline Weeded & 1 & 450.03 & $57.97 * * *$ & 1 & 342.47 & $25.17 * * *$ & 1 & 182.21 & $3.71 \dagger$ \\
\hline Grazed $\times$ weeded & 1 & 71.91 & $9.26 * *$ & 1 & $\ldots$ & $\ldots$ & 1 & $\ldots$ & $\ldots$ \\
\hline Planting density & 1 & 395.19 & $50.90 * * *$ & 1 & 632.72 & $46.51 * * *$ & 1 & 1718.64 & $34.95 * * *$ \\
\hline Weeded $\times$ density & 1 & 73.92 & $9.49 * *$ & 1 & 125.12 & $9.20 * *$ & 1 & 27.10 & 0.55 \\
\hline Error & 104 & 7.76 & & 23 & 13.60 & & 23 & 49.17 & \\
\hline Total & 119 & & & 29 & & & 29 & & \\
\hline
\end{tabular}

$* P=0.05 ; * * P=0.01 ; * * * P=0.001 ; \dagger P=0.067$.

weeding of all nontarget plants as a sub-subplot treatment. Planting density was included as a covariate. Repeated measures analysis was used to test for changes in treatment response over time. Specific treatments were not included in the GLM model when insufficient replication existed within the treatment for proper analysis (e.g., unweeded and ungrazed plots after the second season). To examine the effect of burning on plant growth, data from unburned plots in their second season (1992) were compared to burned plots in their second season (1993). The same was done for third season data (1993 unburned vs. 1994 burned).

Disturbance of the soil within plots by gophers (Thomomys bottae) was a significant cause of Nassella mortality throughout the study, and we measured the amount of disturbance in two ways. First, the number of plots damaged by gophers was analyzed using binomial probability tests (Zar 1984) to detect any relationship between treatments and gopher activity. Second, within the burned experimental areas, the amount of soil disturbance along three $18 \mathrm{~m}$ line transects within each grazing treatment was recorded in January 1995 when disturbance by gophers was highly visible. Data were collected three months after a burn treatment in experimental areas that had not been burned in the preceding three years. These data were analyzed with the SAS General Linear Model for three levels of grazing (ungrazed, spring grazed, summer grazed) in mound and intermound locations with three subsamples per treatment and three replications.

\section{RESULTS \\ Plant growth}

Unweeded plots. - In unweeded plots, burning, grazing, soil depth, planting density (i.e., main effects), or interactions between factors did not have a detectable effect on basal diameter increase in either the second or third season.

Weeded plots. - Planting density had a strong effect on basal diameter increase in both the second and third seasons $(P<0.001$, Table 1$)$. In the second growing season, a burning by planting density interaction $(P<$ 0.01 , Fig. 2) indicated that, at lower densities, increase in basal diameter was greater in burned plots. In addition, a burning and grazing treatment by soil depth interaction $(P<0.01$, Fig. 3$)$ indicated that increase in basal diameter in the second season was greater on mounds than on intermounds, but only in the burnedungrazed plots. No interactions were found among treatments in the third season.

The rate of basal diameter increase of Nassella in response to weeding was greater in burned than in unburned plots. Basal diameter of plants without apparent diffuse competition (i.e., weeded) in burned plots was 94\% greater (second season) and 50\% greater (third season) than plants exposed to diffuse competition. The increase in plant size within unweeded plots compared to weeded plots in the unburned treatment was lower (40\%, second season; $34 \%$, third season; $18 \%$, fourth season) (Fig. 4). Overall, the mean increase in growth in burned plots was two times greater than growth in unburned plots over the second and third seasons. 


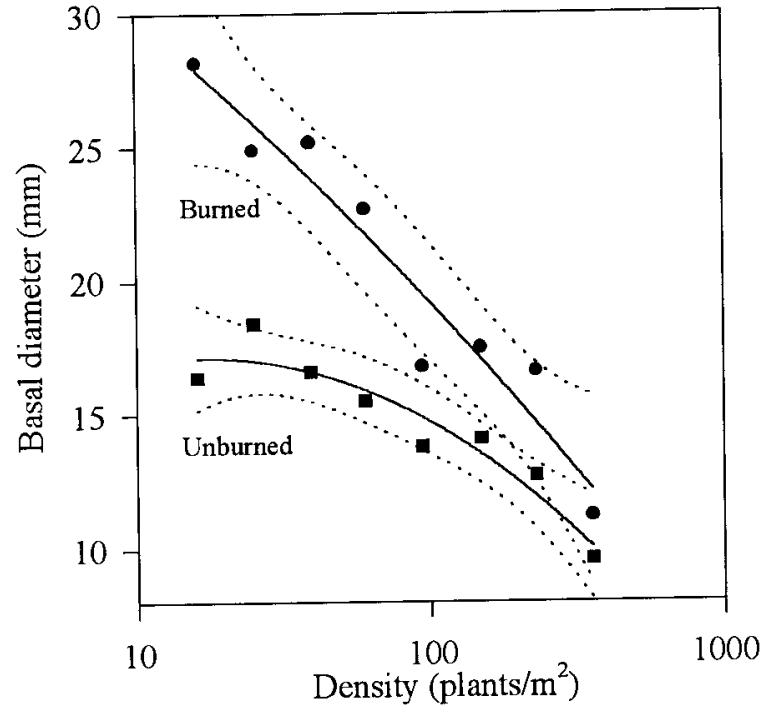

FIG. 2. Relationship between burning treatment and planting density for basal diameter ( $\mathrm{mm}$ ) of Nassella pulchra within weeded plots in the second growing season. A negative exponential curve is used to represent the interaction (unburned $r^{2}=0.91$; burned $r^{2}=0.93$ ). The difference between burned and unburned treatments is significant at $P<0.01$ $\left(F_{3,108}=4.25\right)$. Dotted lines represent $95 \%$ confidence intervals.

Increase in basal diameter was not affected by grazing in any year, and a grazing by weeding interaction was detected only in unburned plots in the second season (Fig. 5, Table 1). Detection of grazing effects after the second season was made less likely because of the loss of plots over time (see data on gopher activity).

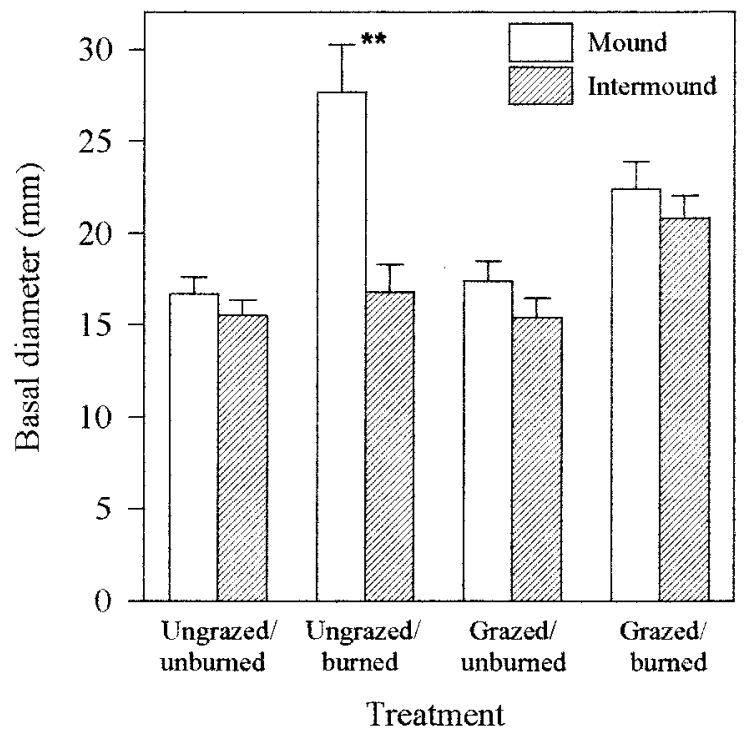

FIG. 3. Basal diameter (mean $\pm 1 \mathrm{SE}$ ) of Nassella pulchra in burning and grazing treatments between two soil depths (mound and intermound) in the second growing season. The difference between mound and intermound plots in the ungrazed/burned treatment is significant at $P<0.01$ (**) $\left(F_{3,108}=4.85\right)$.

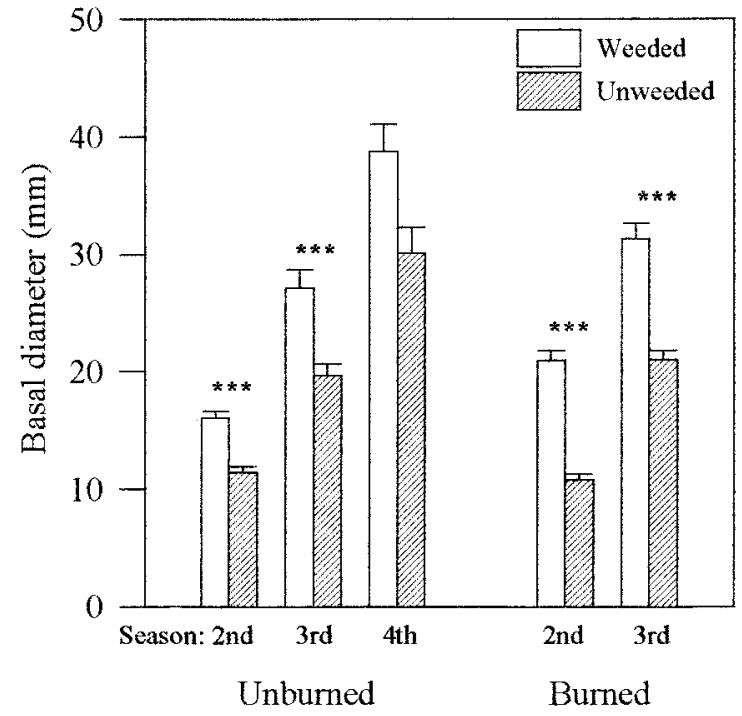

FIG. 4. Increase in basal diameter (mean $\pm 1 \mathrm{SE}$ ) of Nassella pulchra due to weeding in burned and unburned plots. Differences between columns within a growing season are significant at $P<0.001(* * *)$.

Although soil characteristics and depth to the clay layer differed between mounds and intermounds, the topographic location of the plots did not strongly influence growth. The exceptions to this general trend were ungrazed/burned plots $(P<0.01$, Fig. 3$)$, and a soil depth by weeding interaction in burned plots $(P$ $<0.05$, Fig. 6 , Table 1). The interactions were found in the second season only.

Diffuse competition negatively affected basal diameter increase of target plants in all plots, regardless of the level of burning, grazing, or soil depth. Plants

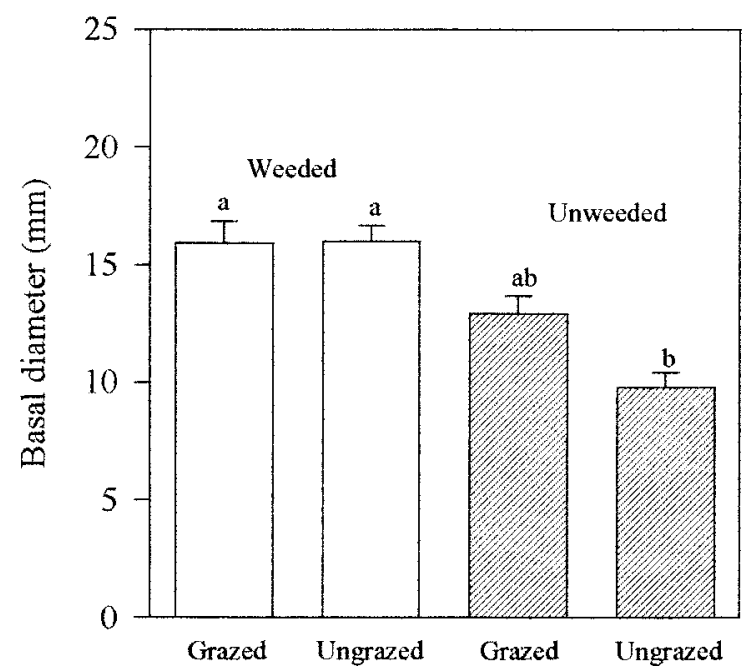

FIG. 5. Grazing by weeding interaction for increase in Nassella pulchra basal diameter (mean $\pm 1 \mathrm{SE}$ ) in unburned plots in the second year. The interaction is significant at $P<$ 0.01 ; the overall effect of weeding is significant at $P<0.001$ $\left(F_{1,104}=57.97\right)$. 


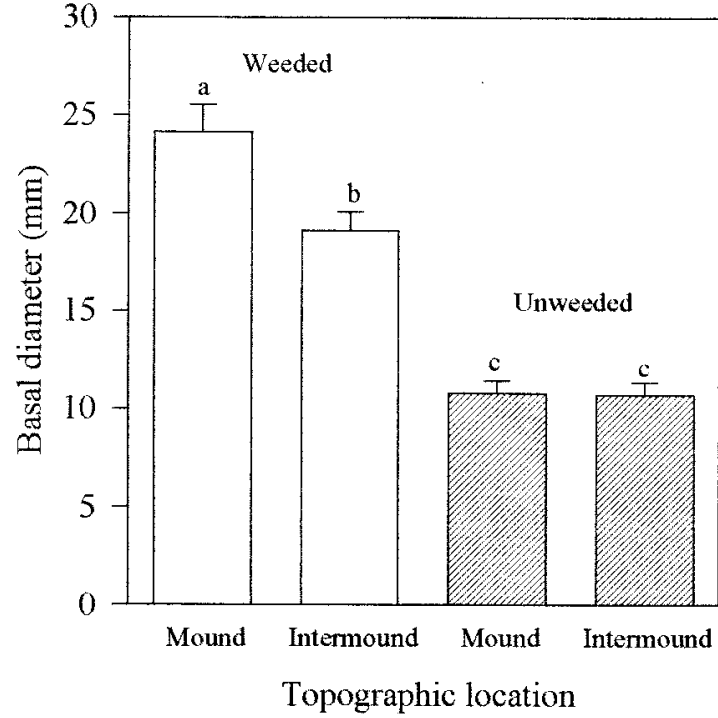

FIG. 6. Soil depth (mound or intermound) $\times$ weeding interaction for increase in Nassella pulchra basal diameter (mean $\pm 1 \mathrm{SE}$ ) in burned plots in the second year of growth. The interaction is significant at $P<0.05$; the overall weeding effect is significant at $P<0.001\left(F_{1,104}=5.91\right)$.

in weeded plots were significantly larger in the second and third seasons regardless of treatment $(P<0.001$, Fig. 4). In addition, growth increased as density decreased $(P<0.001$ both years, Fig. 7$)$. The interaction between planting density and type of competitive environment was significant in both years. From the second year graph (Fig. 7a), it appeared that intraspecific competition was as effective as diffuse competition in suppressing growth at the highest planting density. No effects of planting density were detected in weeded or unweeded plots when burning or grazing treatments were considered simply as main effects.

\section{Plant mortality}

Individual plant mortality was not strongly affected by any treatment factor (i.e., burning or grazing) when analyzed as a percentage of annual mortality. However, mortality of target plants resulting in the elimination of a plot from analysis was significantly higher in unweeded plots $(P<0.01)$. Of the 14 plots that were eliminated from analysis due to high mortality but not damaged by gophers, 12 were unweeded plots. Of the 12 plots that survived intact, 9 were weeded, 10 were grazed, and 9 were on mounds. The highest density rows in each plot were invariably lost after the first year of growth, suggesting a strong intraspecific effect independent of diffuse competition.

Activity patterns of gophers had a strong effect on $N$. pulchra survival. Gopher disturbance was significantly lower within grazed plots $(P<0.01)$ (Fig. 8). Although grazing did not have a significant direct influence on $N$. pulchra growth or survival, the indirect effect of reducing gopher activity resulted in higher plant survival in grazed/burned plots $(P<0.05)$. Gopher activity was partly responsible for the loss of all ungrazed mound plots (weeded and unweeded) by the third season.

Plant mortality attributable to gophers occurred in 19 of 46 plots. Based on binomial probability, gophers were more likely to kill plants in weeded plots $(P=$ $0.05)$, in ungrazed areas $(P<0.05)$, and possibly on mounds $(P<0.1)$. Burning had no detectable effect on gopher activity.
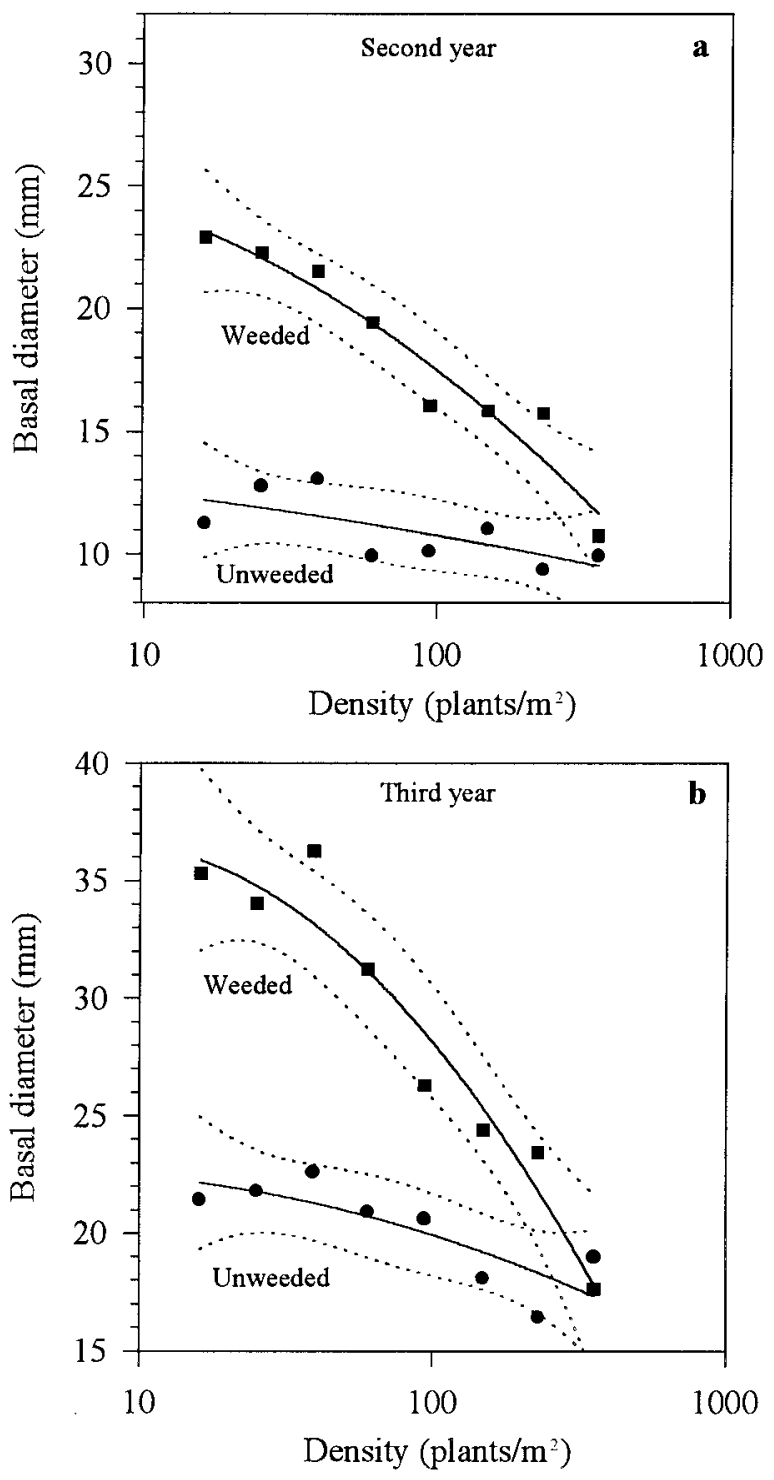

FIG. 7. Relationship between planting density and weeding on increase in basal diameter ( $\mathrm{mm}$ ) of Nassella pulchra, showing the difference between the effects of diffuse and intraspecific competition on growth in each of two growing seasons. Interactions are represented by negative exponential curves. (a) Second year: interaction is significantly different at $P<0.001$, unweeded $r^{2}=0.47$, weeded $r^{2}=0.94$. (b) Third year: interaction is significant at $P<0.01$, unweeded $r^{2}=0.67$, weeded $r^{2}=0.94$. Dotted lines in both graphs represent $95 \%$ confidence intervals. 


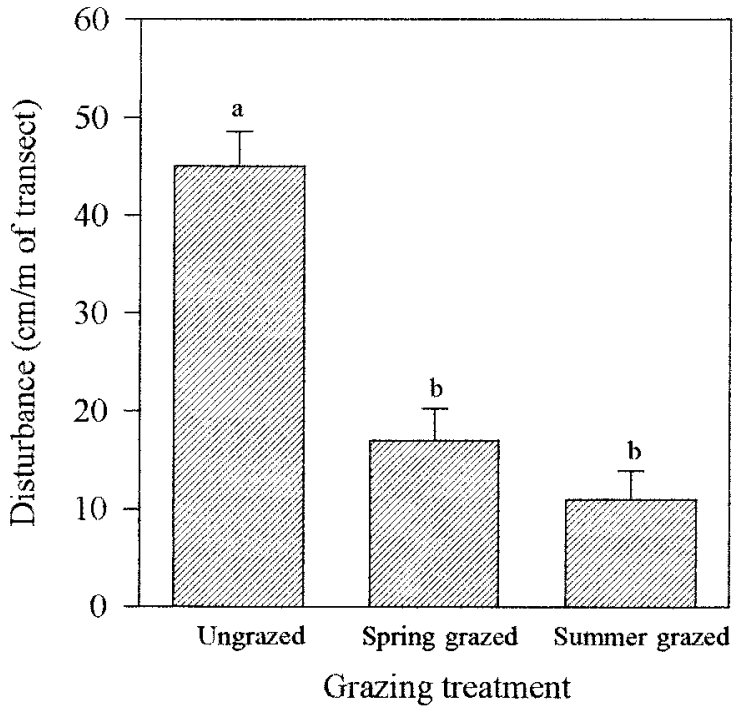

FIG. 8. Amount of gopher activity ( $\mathrm{cm}$ of disturbance/m of transect) in experimental areas subjected to three grazing treatments. Columns with different letters are significantly different at $P<0.001$.

\section{Discussion}

Using plant removal treatments, we showed a strong influence of diffuse competition on basal diameter and survival of N. pulchra. The effect of intraspecific competition on basal diameter increase was also shown, but only in the absence of diffuse competition. The competition provided by a dense multispecies neighborhood of annual plants appears to have an overriding effect on growth and survival of $N$. pulchra, in comparison to both intraspecific competition and to the effects of burning and grazing. Because we did not investigate the effects of other types of neighborhoods (e.g., native annuals) on $N$. pulchra, we cannot reach any conclusions on the competitive environment of the pristine grassland. However, dense neighborhoods of alien annuals appear to be a primary factor in determining the growth and survival of young $N$. pulchra individuals. While nothing is known of the presettlement $N$. pulchra densities and little of recruitment dynamics in natural grasslands today, the inability of $N$. pulchra to re-establish even after being seeded is indicative of the major transformation that has occurred in inland California grasslands. Given the strength of diffuse competition on growth and mortality in this study, our hypothesis that the invasion of alien annual grasses has fundamentally altered the growing conditions for $N$. pulchra would appear to be supported.

The regional distribution of $N$. pulchra in the presettlement grasslands of California was most likely influenced by a combination of edaphic conditions and competition with other native perennials (Bartolome et al. 1980). On a local scale, spacing of mature bunchgrasses suggests that intraspecific competition for one or more limiting resources has influenced long-term plant density. Soil water is the most important limiting factor in the mediterranean environment, particularly in shallow soils (Roy et al. 1987). Within contemporary inland grasslands, light has become an important limiting factor in spring (Schulz and Biswell 1952, Kay and Owen 1970). Thus, light limitation in spring followed by summer competition for soil moisture may reduce the survival of bunchgrass seedlings. Other grassland studies have underscored the importance of spring conditions on subsequent plant growth (Wright and Van Dyne 1976, Aquiar et al. 1992).

As plants mature, we expect mortality to decrease until a density is reached that reflects the site's carrying capacity. Relictual populations of $N$. pulchra in other California locations have densities of 1-7 mature plants $/ \mathrm{m}^{2}$; basal area represents no more than $10 \%$ of the total plant cover (White 1967, Bartolome and Gemmill 1981, Heady et al. 1992). Prior to European settlement of California, the space between mature perennial grasses was probably occupied seasonally by variable densities of native annual grasses, flowering monocots, and annual dicots (Burcham 1961, Wester 1981, Heady 1988).

The rapid conversion of the California prairie to a grassland dominated by alien annual species coincided with decades of heavy, continuous livestock grazing (Burcham 1957, Mack 1989). Intensive year-round grazing in a grassland with no recent history of heavy grazing (Edwards 1992, Painter 1995) represented a massive and prolonged disturbance (Mack and Thompson 1982). Annual European grasses, preadapted to the mediterranean-type climate of inland California and to conditions of seasonal resource availability, clearly found favorable growing conditions. Heavy grazing and European-style agriculture may have created disturbance niches, and some species may have exploited largely unfilled niche space (sensu Grubb 1977).

The rapidity with which nonnative species were able to invade California communities (Burcham 1957, Mack 1989) is indicative of the large-scale disturbance created by the activities of European settlers, as well as the colonizing ability of the many preadapted mediterranean aliens. The overriding negative effect of introduced annual species on the growth and survival of $N$. pulchra is supported in this study by the absence of any effect of burning, grazing, soil depth, or planting density in plots with diffuse competition.

The effect of burning on growth was seen only in plots without diffuse competition, and not after the second season following the burn treatment. The postburn increase in growth may reflect a nutrient flush, a change in soil water availability, or a reduced density of diffuse competitors not seen in unburned plots. Effects of the burning treatment appeared to diminish by the third year, which is consistent with estimates obtained in other California grasslands (Heady 1956, Parsons and Stohlgren 1989, Heady et al. 1992).

We expected differences in soil depth between 
mound and intermound areas to have a significant effect on growth and survival of $N$. pulchra. Coexistence between annual and perennial species, especially among grasses, may be based on the ability of perennials to compensate for slower above ground growth rates by gaining access to deeper soil zones (Berendse 1979, 1982). The region from $0-50 \mathrm{~cm}$ depth is exploited most intensely by annual grasses (Holmes and Rice, in press). Given a soil depth at Jepson Prairie of about $65 \mathrm{~cm}$ on mounds, the mound plots may not represent an area of significantly greater resource availability for perennial grasses. Thus, any differences in growth patterns between the mounds and intermounds would likely be subtle and difficult to detect during a 2-3 yr study. However, the intensity of the interspecific competition effect implies a lack of below ground resource partitioning between $N$. pulchra and the annual neighborhood.

Plant mortality patterns in this study are consistent with earlier results within the same experimental areas. Dyer et al. (1996) recorded $<1 \%$ survival following $>20 \%$ emergence of precision planted N. pulchra seeds. Langstroth (1991) found a 94\% decrease in abundance of $N$. pulchra between the one- and twotillered seedling stage, and a $26 \%$ decrease between the two- and three-tillered seedling stage. In contrast, we found mortality of mature $N$. pulchra was 2-6\% annually over a 7-yr period (Dyer, unpublished data). Therefore, using transplants in the five to ten tiller range, we expected an intermediate mortality rate in our experimental plots.

Throughout most inland California grasslands, native perennial grasses now compete with high densities of aggressive annual species that are potentially better adapted to the contemporary grassland environment. Many annual grasses are adapted to heavy grazing and low nutrient availability (Jackson 1985, Heady et al. 1992). In addition, cool-season annual grasses exhibit rapid growth and rapid resource consumption during periods of slow growth for N. pulchra (Jackson 1985, Jackson and Roy 1986). These alien species have invaded all inland California grasslands even in the absence of obvious physical disturbance.

Grazing by livestock has been recommended as a method for controlling alien annual grasses (Menke 1992) and as a management tool to reduce the suppression of native species by alien annual grasses (Heady 1956). We found no effect of grazing on growth even though the grazing treatment was applied annually. However, all analyses after the second growing season were compromised by the high mortality in ungrazed plots. Although a positive effect of grazing on survival is implied by the data, the high mortality in ungrazed plots was probably a result of greater gopher activity in ungrazed experimental areas. The interaction of grazing and gopher activity in addition to the absence of a grazing main effect makes it difficult to predict long-term effects of grazing on $N$. pulchra growth and survival.

A further complication in assessing the importance of the burning and grazing treatments may be related to the interaction between treatments and the timing of application. The burn treatment was applied in late summer when $N$. pulchra was dormant and after all cool-season annuals had died. In contrast, the grazing treatment was applied in early April, the flowering time of many cool-season annual species and a phase of rapid growth for $N$. pulchra. Application of a spring grazing treatment is intended to decrease the aboveground biomass of annual species at a time of high resource availability. However, the grazing treatment also defoliates the perennial grasses and reduces their ability to take advantage of the favorable conditions (Briske and Richards 1994).

We conclude that high densities of invasive alien species have fundamentally altered growing conditions in the California grassland. This alteration probably reflects a reduction of limiting resources such as light in spring and water in early summer (Kay and Owen 1970). We conclude that the application of burning and grazing intended to reduce diffuse competition has had no short-term effect on $N$. pulchra growth. Although potentially favoring native perennials, these treatments did not create unfavorable conditions for alien annuals.

ACKNOWLEDGMENTS

This work was supported by The Nature Conservancy (contract CARO-121993-R). The authors wish to thank the Hamilton family, Oren Pollak, Ken Taggard, Eric Knapp, Marcel Rejmanek, Paul Gepts, Norma Fowler, Richard Mack, and two anonymous reviewers for support, assistance, and valuable comments.

\section{Literature Cited}

Antonovics, J. A., and N. L. Fowler. 1985. Analysis of frequency and density effects on growth in mixtures of Salvia splendens and Linum grandiflorum using hexagonal fan designs. Journal of Ecology 73:219-234.

Aquiar, M. R., A. Soriano, and O. E. Sala. 1992. Competition and facilitation in the recruitment of seedlings in Patagonian steppe. Functional Ecology 6:66-70.

Bartolome, J. W. 1979. Germination and seedling establishment in California annual grassland. Journal of Ecology 67:273-281.

Bartolome, J. W., and B. Gemmill. 1981. The ecological status of Stipa pulchra (Poaceae) in California. Madroño 28:172-184.

Bartolome, J. W., S. E. Klukkert, and W. J. Barry. 1986. Opal phytoliths as evidence for displacements of native California grassland. Madroño 33:217-222.

Bartolome, J. W., M. C. Stroud, and H. F. Heady. 1980. Influence of natural mulch on forage production on differing California annual range sites. Journal of Range Management 33:4-8.

Berendse, F. 1979. Competition between plant populations with different rooting depths I. Theoretical considerations. Oecologia 43:19-26.

. 1982. Competition between plant populations with different rooting depths III. Field experiments. Oecologia 53:50-55.

- 1983. Interspecific competition and niche differentiation between Plantago lanceolata and Anthoxanthum 
odoratum in a natural hayfield. Journal of Ecology 71:379390.

Briske, D. D., and J. H. Richards. 1994. Physiological responses of individual plants to grazing: current status and ecological significance. Pages 147-176 in M. Vavra, W. A. Laycock, and R. D. Pieper, editors. Ecological implications of livestock herbivory in the west. Society for Range Management, Denver, Colorado, USA.

Burcham, L. T. 1957. California Range Land. California Department of Forestry, Sacramento, California, USA.

1961. Cattle and range forages in California: 17701880. Agricultural History 35:140-149.

Clements, F. E. 1934. The relict method in dynamic ecology. Journal of Ecology 22:39-68.

Dyer, A. R., H. C. Fossum, and J. W. Menke. 1996. Emergence and survival of Nassella pulchra in a California grassland. Madroño 43:316-333.

Edwards, S. W. 1992. Observations on the prehistory and ecology of grazing in California. Fremontia 20:3-11.

Evans, R. A., and J. A. Young. 1972. Competition within the grass community. Pages 230-246 in V. B. Youngner and C. M. McKell, editors. The biology and utilization of grasses. Academic Press, New York, New York, USA.

Goldberg, D. E. 1987. Neighborhood competition in an oldfield plant community. Ecology 68:1211-1223.

Grubb, P. J. 1977. The maintenance of species-richness in plant communities: the importance of the regeneration niche. Biological Review 52:107-145.

Heady, H. A. 1956. Changes in a California annual plant community induced by manipulation of natural mulch. Journal of Range Management 37:398-812.

- 1988. Valley grassland. Pages $491-514$ in M. G. Barbour and J. Major, editors. Terrestrial vegetation of California. Wiley Interscience, John Wiley and Sons, New York, New York, USA.

Heady, H. F., J. W. Bartolome, M. D. Pitt, G. D. Savelle, and M. C. Stroud. 1992. California prairie. Pages 313-335 in R. T. Coupland, editor. Natural grasslands. Elsevier Science, Amsterdam, The Netherlands.

Huenneke, L. F. 1989. Distribution and regional patterns of California grasslands. Pages 1-12 in L. F. Huenneke and H. Mooney, editors. Grassland structure and function: $\mathrm{Cal}$ ifornia annual grassland. Klewer Academic, Dordrecht, The Netherlands.

Holland, R., and S. Jain. 1988. Vernal pools. Pages 515-533 in M. G. Barbour and J. Major, editors. Terrestrial vegetation of California. Wiley Interscience, John Wiley and Sons, New York, New York, USA.

Holmes, T. H., and K. J. Rice. The role of life history in the soil-moisture dynamics of a Mediterranean woodland community. Annals of Botany, in press.

Jackson, L. E. 1985. Ecological origins of California's mediterranean grasses. Journal of Biogeography 12:349-361.

Jackson, L. E., and J. Roy. 1986. Growth patterns of mediterranean annual and perennial grasses under simulated rainfall regimes of southern France and California. Acta Oecologica/Oecologia Plantarum 7:191-212.

Kay, B. L., and R. E. Owen. 1970. Paraquat for range seeding in cismontane California. Weed Science 18:238-243.

Langstroth, R. P. 1991. Fire and grazing ecology of Stipa pulchra grassland: a field study at Jepson Prairie. Thesis, University of California at Davis, Davis, California, USA.

Littell, R. C., R. J. Freund, and P. C. Spector. 1991. SAS systems for linear models, Third edition. SAS Institute, Cary, North Carolina, USA.

MacArthur, R. H. 1972. Geographical ecology: patterns in the distribution of species. Harper and Row, New York, New York, USA.

Mack, R. N. 1989. Temperate grasslands vulnerable to plant invasion: characteristics and consequences. Pages 155-179 in J. A. Drake, H. A. Mooney, F. DiCastri, R. H. Groves, F. J. Kruger, M. Rejmanek, and M. Williamson, editors. Biological invasions: a global perspective. John Wiley and Sons, New York, New York, USA.

Mack, R. N., and J. N. Thompson. 1982. Evolution in steppe with few large, hooved mammals. American Naturalist 19: 757-773.

Major, J., and W. T. Pyott. 1966. Buried, viable seeds in two California bunchgrass sites and their bearings on the definition of a flora. Vegetatio 13:253-282.

McNaughton, S. J. 1968. Structure and function in California grasslands. Ecology 49:962-972.

Menke, J. W. 1992. Grazing and fire management for native perennial grass restoration in California grasslands. Fremontia 20:22-25.

Painter, E. L. 1995. Threats to the California flora: ungulate grazers and browsers. Madroño 42:180-188.

Parsons, D. J., and T. J. Stohlgren. 1989. Effects of varying fire regimes on annual grasslands in the southern Sierra Nevada of California. Madroño 36:154-168.

Roy, J., E. Garnier, and L. E. Jackson. 1987. Response of two perennial grasses to water availability in different habitats related to successional change under mediterranean climate conditions. Pages 175-190 in J. D. Terhunen, F. M. Catarino, O. L. Lange, and W. C. Oechel, editors. Plant responses to stress: functional analysis in mediterranean ecosystems. Springer-Verlag, Heidelberg, Germany.

Schulz, A. M., and H. H. Biswell. 1952. Competition between grasses reseeded on burned brushlands in California. Journal of Range Management 5:338-345.

Stromberg, M. R., and J. R. Griffin. 1996. Long-term patterns in coastal California grasslands in relation to cultivation, gophers and grazing. Ecological Applications 6:11891211.

Talbot, M. W., H. H. Biswell, and A. L. Hormay. 1939. Fluctuations in the annual vegetation of California. Ecology 20: 394-402.

Wester, L. 1981. Composition of the native grasslands in the San Joaquin Valley, California. Madroño 28:231-241.

White, K. L. 1967. Native bunchgrass (Stipa pulchra) on Hasting Reservation, California. Ecology 48:949-955.

Wilson, S. D., and P. A. Keddy. 1986. Measuring diffuse competition along an environmental gradient: results from a shoreline plant community. American Naturalist 127: 862-869.

Wright, R. G., and G. M. Van Dyne. 1967. Environmental factors influencing semidesert grassland perennial grass demography. Southwest Naturalist 21:259-274.

Zar, J. A. 1984. Biostatistical analysis. Prentice Hall, New York, New York, USA. 